\title{
THE BIRTH OF A CINEMATIC STORYLINE NORMALIZING VIOLENCE AGAINST BLACK LIVES
}

\author{
James Curiel \\ Norfolk State University
}

Shootings of people of color, the poor, women, and liberals have increased in recent years, and as police shootings increase, so do mass public shootings in an intolerable level of gun violence throughout the United States. The 2012 killing, some assert persuasively the "murder," of Trayvon Martin spurred actions by a group naming itself the Dream Defenders to demand the arrest of George Zimmerman and the firing of the Sanford Police Chief (McLain 19-20). The July 13, 2013 acquittal of Zimmerman led Alicia Garza and Patrisse Cullors to create the Black Lives Matter movement through social media as Garza's expression "Black people, I love you. I love us. Our lives matter" went viral with Cullors' hashtag (Altman 118). The British newspaper, The Guardian's "The Counted" crowd sourced database found that United States police killed 1,146 persons in the year 2015, with Blacks two times more likely than whites to be killed by the police. Law Professor Cynthia Lee notes that "Blacks and Latinos constitute only thirty percent of the United States population but make up fifty-six percent of the inmates in prisons and jails across the country (Lee 482)." Nelson notes the historical disregard of the bodies and health of Blacks, minorities, and the poor throughout history, and Rickfort documents the Black Lives Matter movement's use of social media to build a coalition in the streets battling new violence re-enforcing old racial hierarchies in the age of the Obama Presidency (Nelson 1734; Rickfort 35).

In order to figure out how old racial hierarchies remain alive in our consciousness, we should examine the stories, the myths, that we tell in our popular culture. Campbell argues that myths serve as a model for how to see the world, observing that the most developed myth is the ameliorative myth, one which affirms the world according to how we think it should be (Campbell 4-6). Cultural critic Walter Benjamin noted films are the most powerful art form for shaping mass consciousness and serving political purposes (Benjamin). D. W. Griffith, the landmark Hollywood director, said film was the most powerful medium because the artificiality of the medium was hidden from the viewer and it was as if they were "present at the making of history" itself (Rogin 186, 194). Vaughn argues that the repetition of accepted myths limit social and po- 
litical dialogue when "mythic reality becomes resistant to change because it has defined the terms that constitute a given culture's perspective (423-435)." Movies remain in the powerful narrative in United States culture to this day.

It is in this context that we should re-examine the most successful and influential movie of all time, The Birth of a Nation. D.W. Griffith's movie The Clansman premiered at Clune's Auditorium in Los Angeles on February 8, 1915. By March, Thomas Dixon, whose works the movie is based upon, had renamed it The Birth of a Nation and it was playing in New York and in the White House (Henderson 155-157). By 1946, over 200 million people had seen the film while 200 film critics labeled it the greatest film in the first fifty years of the cinema (Pitcher 50; Rogin 150). The Birth of a Nation became the most successful movie of all time in terms of dollars adjusted for inflation and the number of tickets sold relative to the population (Pitcher 50). The first blockbuster film gave birth to Hollywood becoming the movie Mecca of the world, and it was the first film to be distributed to live theaters while charging live theatre prices of $\$ 2$ a ticket (Stokes 3; Brown 98; Henderson 159). The Birth of a Nation has been cited as establishing film as an art form, motion pictures as an industry, modern movie distribution, and cinema conventions, such as cross-cutting, panning, the close-up, and using the camera, lighting, editing, and music to enhance the story being told (Stokes 3-9; Niderost 62). However, for all the accolades, controversy, and cinematic importance of the film, there has been an absolute silence about the most successful film in history establishing a conventional storyline. This silence on establishing a storyline imprinted on subsequent movies seems particularly incredulous in Hollywood where 'success breeds imitation' is both gospel and bane in a town where commercialism and creativity are constantly in tension.

This article circumvents the silence by: defining the conventional storyline in The Birth of a Nation, and by exposing its undeniable presence and popularity in successful Hollywood films, such as Gone with the Wind, Fort Apache, The Omega Man, and The Outlaw Josie Wales. It is fashionable today to abhor the repugnant racism in The Birth of a Nation, but the question I ask is, "If the storyline in The Birth of a Nation itself is racist, sexist and promotes murder should it not make all films using the same storyline no less repugnant? If we measure the answer according to commercial success the answer throughout history and into the present is no because many of the most successful films at the box office have employed The Birth of a Nation's storyline. 


\section{Conventional Storyline}

The Birth of a Nation contains a storyline where white conservatives use gun violence to remove progressives, people of color, and feminists from power in order to re-establish a patriarchal colonial order. This narrative contains four themes that can be categorized as the following: First, people of color, feminists, and progressives pose a threat to the family and social order (i.e., patriarchal, colonial order). Second, a white male savior, who has been resurrected from the dead, neutralizes the threat. Third, a renegade military provides a violent solution to the conflict, and fourth, challenges to patriarchy and the traditional racial hierarchy are eradicated and equilibrium is restored in a return to male domination and the neo-colonial racial order. This storyline and four themes are common to the books and plays by Thomas Dixon and D.W Griffith's movie (Dixon 1902; Dixon 1905a; and Dixon 1905b).

In The Birth of a Nation, people of color, progressives, and women become the monsters that threaten the conservative social order, a social order in which slaves exist in a hell of perpetual servitude while the poor subsist on wages barely adequate for survival. Similar to Dixon's books, the movie claims wealthy whites are the true victims of the Civil War and Reconstruction, a fictional world where morality is inverted and then is presented as being factual. The opening card for the movie reads:

We do not fear censorship, for we have no wish to offend with improprieties or obscenities, but we do demand, as a right, the liberty to show the dark side of wrong, that we may illuminate the bright side of virtuethe same liberty that is conceded to the art of the written word-that art to which we owe the Bible and the works of Shakespeare.

This framing echoes Dixon's books and plays which he claimed to being factual and objective (Dixon, 1905b, 16; Okuda 218), but notice how the association of black with "wrong" and white with "bright side of virtue" perfectly illustrate Malcolm X's critique of negative associations with blackness that reinforce Jim Crow stereotypes (Haley 178). This is the subtle start to the monsterizing taking place from the beginning of the film, and in less than twenty seconds the film devolves further into historical and moral inversion when the title card declares "The bringing of the African to America planted the first seed of disunion." Three black men in chains are shown being put on the auction block. In Dixon's and Griffith's 'factual' world, the three slaves being sold are the perpetrators of human suffering, for they are not the victims but the agents of disunion. The whites buying the slaves, selling the slaves, and whipping the slaves are innocent victims. Dixon repeatedly states throughout his 
books that the African is responsible for the lives lost and money expended on the Civil War. Heaven forbid anyone identify the South as causing the Civil War even if they take the Southern position that the war was about secession or "state's rights", not slavery. In Dixon's and Griffiths' inverted reality, the African planted the seed of disunion, for the Africans themselves were the 'bad seeds.'

The demonizing of progressives continues with their Congressional leader, the character Austin Stoneman. We first meet Stoneman with Elsie, his daughter, helping him to put on his toupee. The toupee symbolizes Stoneman's loss of hair, vanity, superficial nature, and false sense of personhood. Similar to Samson being sheared, the bald Stoneman is an emasculated male. He is not a real man. In his opening scene he is sitting down with a shawl around his shoulders, like an old woman. Stoneman is not a real person, for he is as fake as his hair. The hair in his wig is visually different and strange. To the contemporary eye the texture appears coarse and artificial, as if it could only be synthetic, but this movie was made in 1914, two decades before nylon and other synthetic fibers came into market existence. The wig is made from black, kinky hair that has been straightened through acid treatment. The hair is symbolically important because Director Griffith had to special order such an item. Stoneman's wig, like his politics, symbolizes the betrayal of his race.

Beyond Stoneman's betrayal of his race, The Birth of a Nation is a film of comparison and contrast, a story of black and white, good and evil, progressives and conservatives, North and South, the push for equal rights and the push for black disenfranchisement. Austin Stoneman is the patriarch of the Stoneman family representing the North, the progressives, Reconstruction, and the push for Equality. Doctor Cameron is the patriarch of the Cameron family who represents the South, the conservatives, and the push for disenfranchisement of blacks. Austin Stoneman becomes demonized as that which is bad in this process of comparison and contrast while Doctor Cameron is presented as genteel benevolence, the embodiment of all that is good. Austin Stoneman is shown inside, frail, emasculated complete with wig and shawl, surrounded in his library with books he does not read, his books being pretentious decorations as false as the hair on his head. He is supposed to have a club foot, like Thaddeus Stevens, the real life Congressional leader upon which he is based, and Griffith has the actor Ralph Lewis portray Austin Stoneman by wearing an extreme platform shoe, on his left foot that forces him to walk with a gate reminiscent of Charles Laughton in the Hunchback of Notre Dame (1939) or Roddy McDowall in Planet of the Apes (1968). It is a walk that makes him frail, grotesque, and beastly. He is usually seen alone, for he lives apart from his children. He does not initiate hugging 
with his children, and when Elsie goes to hug him it is an awkward occasion, as if he does not know how to love.

On the other hand, we have Doctor Cameron, the sage with white long hair, his real hair. In the first shot with him, he is outside, a real man's province, on his porch with kittens and puppies. He is reading a newspaper for he is a man of the world concerned with real events, not dusty, pompous idolatry of books. His chair on a large porch, the width of the house, is surrounded not only by fawning baby animals, but also by friends and family. Doctor Cameron is a family man, and he is always seen with his family throughout the film. This looms in contrast to Stoneman's solitary chair by a small table that forces guests and family to stand. The Camerons represent a family staying together against all odds when a war takes two of their sons as well as their wealth. Stoneman represents the disintegration of family due to misplaced ideals pushing for equality that lead to betrayal of oneself and betrayal of one's race. This is a contrast between progressives sacrificing family for false ideas while conservatives save family in the face of the progressive decay forced upon communities.

The ideals of community come to light in The Birth of a Nation when the sons go off to war, and during Reconstruction when we see the consequences of giving blacks equal rights. The Cameron sons and the sons of the South dance all night in uniform at a ball that is proper and chaperoned. In the morning when the bugle call for assembly beckons the troops to march off to war, the streets are filled with slaves and whites cheering. The entire community, the entire system of master and slave, is one happy family, united in spirit and mind. Compare this to when the Stoneman boys in the North head to war where there is no ball, there is no ceremony. There is only Elsie on the street with them, their father nowhere to be seen. There are three disinterested black men in the distant background that could care less. The Aunt is sitting in a chair on her super small porch waving goodbye. After her two brothers leave, Elsie runs back to her aunt and falls into the aunt's arms weeping, but the porch is so small there is no room for Elsie on the porch, leaving her to fall to its steps. Unlike the Cameron porch, the porch to the aunt's house, where the Stoneman children have lived and grown up, there is no room for family. Unlike the Cameron send-off, the Stoneman brothers leave with no bands playing, no dancing in the streets. The Stoneman brothers leave with the streets empty, the three blacks in the background entirely oblivious to them, the community absent like their father, isolated and disconnected.

Disconnected from family and community, Austin Stoneman has no mercy, wisdom, or decency. In post-war negotiations with President Lincoln, Austin demands that the rebel leaders be hanged and that the 
white South must be subjugated until it accepts equal rights for all its citizens. Lincoln is portrayed as the voice of reason and wisdom, who does not seek revenge, but wants to leave the South to its own devices, meaning free for whites to subjugate blacks with disenfranchisement. Austin, the false prophet with false hair, wants hangings, revenge and servitude thrust upon a vanquished foe. The news of Lincoln's assassination does not bring tears or grief to Austin or to his live-in companion, his temptress mulatto maid, Lydia. Instead, Lydia smiles with glee and begins rubbing her greedy grubby hands together as she proclaims to her seduced employer, "You are now the greatest power in America." In contrast, on the Cameron porch the entire family falls into grief as Doctor Cameron reads from the newspaper about Lincoln's death. "The New South" titled newspaper reads, "It has thrown our community in the deepest gloom" and Doctor Cameron declares, "Our best friend is gone." In other words, the Camerons understand the true meaning of the tragedy while the progressive family has no honor, for the assassination is trivialized as a political opportunity to inflict suffering upon a defeated foe.

During Reconstruction, we find out the true character of the black community in Dixon and Griffith's fictional world of The Birth of a Nation. It is symbolized in the licentious Lydia Brown who uses sex to control Austin Stoneman to the point of having him living in a house separated from his children. Blacks live to deceive themselves and all those around them, for in the end Lydia has fooled Stoneman for her true lover is Silas Lynch, but Silas Lynch has used sex to control Lydia, so Stoneman will help make Lynch Lieutenant Governor. Silas covets not Lydia, but Stoneman's daughter Elsie and it is she he intends to marry. Lydia has fooled Stoneman, and Silas has fooled Lydia, just like blacks have fooled the educated northerners into believing that blacks can be equal with whites.

In Dixon's inverted world, blacks retrogress into primitives when given freedom, primitives who ultimately will marry white women. Throughout the movie, signs are displayed calling for abolition of slavery and equal rights for blacks. These signs frequently read, "Equal Rights, Equal Politics, Equal Marriage" where inter-racial marriage is the bottom line literally and figuratively. In the state houses, black legislators are shown at their desks with their dirty boots on desktops, drinking hard liquor, eating fried chicken, and taking off their shoes to reveal sockless, uncouth and uncultured feet. Upon winning the vote to legalize interracial marriage, the black solons and observers in the gallery go wild jumping up and down and dancing for joy as if the highest priority for the black race, including black women, is for black men to cohabitate with white women. The whole point of the black legislators seems to be in line with Stoneman's revenge. A title card reads, "The policy of con- 
gressional leaders wrought. . . a veritable overthrow of civilization in the South. . . . in their determination 'to put the white South under the heel of the black South,' Woodrow Wilson." The frequent quotes of this attitude from Wilson's books place him ideologically next to his best friend and roommate from graduate school, Thomas Dixon (Cook 13).

Carpetbaggers go through the town of Piedmont telling slaves to put their hoes down because they are now free, and the carpetbaggers proceed to drink alcohol and dance with blacks in the streets where the negroes are eating fried chicken and watermelon. The carpetbaggers drag blacks to get in line at the Freedman's Bureau where they are handing out free tools and seeds to blacks. The title card reads "The Freedman's Bureau. The Negroes getting free supplies. The charity of a generous North misused to delude the ignorant."

Blacks and progressives are caricatures of chaos and ignorant knaves. In other words, progressives and blacks are not real people. They are as false as Austin Stoneman's wig, and are rotting material that produces odor. These caricatures have been replayed over and over again against progressives and blacks, and they were highly successful in forming conventions to be followed in subsequent Hollywood movies. In The Birth of a Nation, progressives, blacks, and women are a threat to law and order, they tax and spend you into oblivion, and they are not real people, but are a real threat to all that is "decent." They are monsters that will destroy the world.

The world needs to be saved from these monsters, and the hero in The Birth of a Nation is Ben Cameron. He fits the mold of the second theme when he is resurrected from the dead and saves the world by neutralizing the monstrous threat of equality. Ben Cameron leads his Confederate soldiers on a daring charge into the Union lines. In his charge he carries the Confederate flag and is shot multiple times. He is captured and sent to a hospital in Washington, D.C., where he almost dies. In the hospital he meets Elsie Stoneman, raising his spirits as he has carried a photo of her in his pocket throughout the war. He is resurrected from the dead, but he is again doomed to death because he is going to be executed as a rebel guerilla. He is resurrected a second time when President Lincoln pardons him.

Lincoln's pardon allows Ben to return to his hometown, Piedmont, where the black troops will not let him walk on the same sidewalk with them. The black troops are a threat to social order, for they kill negroes loyal to the master, use rifles to stop whites from voting, and encourage legal judgments by black judges and black juries to go against victimized white defendants. The situation is simply scandalous, and the third theme comes into play when Ben leads a renegade military consisting of the $\mathrm{Ku}$ Klux Klan to ride in and save the day. 
The fourth theme of the renegade military re-establishing patriarchal colonial order comes by Ben leading the Ku Klux Klan in re-establishing white control by defeating an all-black United States Army in the streets of Piedmont. Subsequently, the Ku Klux Klan uses the threat of the rifle to stop blacks from voting and to re-establish the patriarchal colonial power of the white southern male. Disenfranchisement takes place through the violence of the rifle, just as in the case of the only successful coup d'etat in United States history, the overthrow of the elected government in Wilmington, the most populous city in North Carolina, in 1898 when Silas White was Mayor (1898 Wilmington Race Riot Commission). The white savior and his paramilitary group in The Birth of a Nation use the gun to remove Silas Lynch from power and to stop blacks from voting, and, thus, the four themes are central to the problem and solution in The Birth of a Nation's storyline.

\section{Gone WiTH THE WiND (1939)}

The success of Gone with the Wind as both a book and as a movie cannot be overlooked. Similar to Dixon's book The Leopard's Spots, Gone with the Wind sold over a million copies in its first year of publication (Stokes 42; Lambert 27). What is different, however, is Gone with the Wind was critically acclaimed and was awarded the Pulitzer Prize (Lambert 27). Similarly, Gone with the Wind the movie was the box office champ from 1939 to 1966, and during its many theatre releases it has been estimated to have earned $\$ 390$ million dollars at the box office, or approximately 3.3 billion dollars when adjusted for inflation. The film also won eight competitive Academy Awards, including Best Picture, Best Director, Best Actress, Best Screenplay, and Best Supporting Actress (www.oscars.org/oscars/ceremonies/1940). While Gone with the Wind echoed the commercial success of The Birth of a Nation, the public attitude towards the two in the present could not be more different for The Birth of a Nation is reviled as racist melodrama while Gone with the Wind is revered as classic entertainment. The infamy of The Birth of a Nation could not be more clear cut than its black and white prints while the popularity of Gone with the Wind remains as colorful as its Technicolor stock shot by Haller and Rennahan.

The discrepancy between the public's vilification of the one and adoration for the other remains a little queer when one considers that Margaret Mitchell was an avid reader of Thomas Dixon's books, to the point of writing "I was practically raised on your books, and love them very much" (Harwell 52; Slide 192). What makes it all the more interesting is the same attitudes and storyline of The Birth of a Nation can be found in Gone with the Wind. 
The reader may respond defensively that Gone with the Wind is a love story of survival in the face of insurmountable odds, and the main protagonist of the story is female, so how is it possible that it contains the same storyline and attitudes as The Birth of a Nation? Finding the same racist attitudes in Gone with the Wind is not difficult as the book is laced with white supremacist drivel espoused by Southern radicalist writers like Thomas Dixon. Narration from Margaret Mitchell's book expresses this throughout the book, as in the following examples:

There they conducted themselves as creatures of small intelligence might naturally be expected to do. Like monkeys or small children turned loose among treasured objects whose value is beyond their comprehension, they ran wild-either from perverse pleasure in destruction or simply because of their ignorance (Mitchell 434)

Confronted with the prospect of Negro rule, the future seemed dark and hopeless, and the embittered state smarted and writhed helplessly. As for the Negroes, their new importance went to their heads, and realizing that they had the Yankee Army behind them, their outrages increased. No one was safe from them (Mitchell 517).

The Southern radicalist philosophy reads like it was lifted straight from the pages of Dixon's The Leopard's Spots, one of the main books The Birth of a Nation is based upon (Gillespie and Hall 49). In it is the same notion of the United States Army not being the real army, for it is the 'Yankee Army,' a stooge serving ignorant Darkies, misguided liberals, and Northerners bent on revenge. These sentiments remain in the movie as do the four themes found in the storyline of The Birth of a Nation.

The first theme of people of color, feminists, and progressives being a threat to the family and human existence is absolutely in play in Gone with the Wind the movie as it is an idealized contrast between fairytale notions of what is prim and proper, and what is indecent and immoral. The film opens with images of contented slaves working in fields and picking cotton, sweeping portraits of grand mansions, and placid scenes of rivers and sunsets. This perfect world and its implied contrast are further punctuated with the opening title cards, more fit for a silent movie than a modern talkie that read:

There was a land of Cavaliers and cotton fields called the Old South. . . Here in this pretty world Gallantry took its last bow. Here was the last ever to be seen of Knights and their ladies Fair, of Master and of Slave. . . Look only for it in books, for it is no more than a dream remembered. A Civilization gone with the wind. . . 
In the movie, as in the book, the patriarchal, conservative social order of white master-black slave, male rule-female subordination, upper classlower class, of prized citizenry and outcast aliens is a world of idyllic equilibrium where somehow all involved, including the slaves and aliens, are happy and fulfilled. The story itself, and the characters within the story, are a textbook case of contrasts between supposed opposites, and in this fairytale, patriarchal Caucasian supremacy is the social order that is "pretty" and the "dream" of what is moral and what should be.

Conversely, the world of equality is an evil and chaotic nightmare where human beings become despicable. Every slave on the plantation has the potential to be evil by leaving the tranquility of the slave life to pursue freedom. Every woman has the potential to be evil by leaving the tranquility of married life to pursue freedom and independence. Every person has the potential to evil by leaving the tranquility of conservatism to pursue advocating liberalism and egalitarianism.

Most of the slaves leave Tara when the Union troops are near, and these slaves become evil. Mammy and Prissy remain at the plantation as members of the old order at Tara, so they are sanctified. Big Sam becomes evil when he leaves and lives in Shantytown. However, he saves Scarlett from robbery and rape while she is passing Shantytown, and heads home to Tara and the old order and becomes sanctified as a prodigal son who has gone astray and returned home.

Women who challenge tradition are scandalous and lost. Prostitutes go their own way, and have fallen. In the film there is a running tension between prostitute women, who wear colored clothes, colored hair, and make-up, and married women who wear conservative clothes. The independent Scarlett often wears dresses, such as bright red and bright green, that place her in the prostitute camp. Women in the film are also characterized as gossips, fainting from weakness, emotional sobs, and, like Scarlett, they are manipulators.

The Yankees who fight to end slavery are evil beyond redemption. Sherman and the United States Army are the "Great Invader" that inflicts destruction and injustice upon the South. Continually, U.S. Army soldiers are shown to be depraved robbers and rapists, such as the deserter who goes rummaging for things to steal at Tara and approaches Scarlett with bodily desire. Before he is shot, he asks Scarlett, "Got anything else besides these ear bobs?" and she replies, "You Yankees have been here before." The meaning is the Yankees have already stolen everything else, for they are nothing but an army of thieves.

With the end of the war the Yankees steal the Southern way of life and destroy it. With the war over, taxes due, and no slaves, Scarlett's sisters are reduced to picking cotton in the fields of Tara. One sister says, "My back's near broke. Look at my hands. Mother says you can 
always tell a lady by her hands." And the other sister replies, "I guess things like hands and ladies don't matter so much anymore." Harkening back to the opening title cards, we are supposed to feel anger over these ladies having to suffer. Harkening back to the opening visuals, the Southern Radicalist viewpoint is that blacks are made for backbreaking work, for they are not really human (Gillespie and Hall 48). Thus, in the beginning when we see blacks hoeing the fields and picking cotton everything is pleasant and as it should be. There is no oppression, and there is no pain in their backs and hands. But, when we see Scarlett's sisters picking cotton we feel the pain and the world has been turned upside down, and the U.S. Army is to blame for it.

The only thing worse than the U.S. Army are liberals who come down to the South to educate blacks, push for social equality, and work for black suffrage. These liberals are called 'Carpetbaggers' in the parlance of the Southern Radicalists. The movie explicitly proclaims this when the title cards read, "Home from their lost adventure came the tattered Cavaliers. . . Grimly they came hobbling back to the desolation that had once been a land of grace and plenty. . . And with them came another invader. . . more cruel and vicious than any they had fought. . the Carpetbagger." Then immediately we see crippled and one-legged Confederate veterans straggling home on a dirt road, and there in the road is a buggy with . . . carpetbaggers. One of the carpetbaggers is white, the former overseer at Tara, Jonas Wilkerson. The other carpetbagger is black. Both of them are dressed as dandies, replete with white shirts with starched collars, expensive gloves, hats, vests, and the black man has a gold handled cane, gold watch, ascot, and cigar. Jonas is the chauffeur, as if to emphasize the scandalous social inversion of a white man playing caddy to a black man. These two liberals are completely oblivious to the suffering Confederate soldiers along the road. In fact, Jonas has to stop the carriage because two soldiers are in the way, and he admonishes them, "Get out of the road rebel, get out of the way!" One of the Confederate soldiers replies, "Have you room in your cab for a dying man?" Jonas Wilkerson represents the liberal devoid of human sympathy and compassion and says, "I've got no room for no Southern scum alive or dead. Get out of the way!" Wilkerson then whips the horse and practically runs over the dying Confederate soldier while the black carpetbagger curtly snarls, "Act like they won the war!" Nonchalantly running over a dying veteran with malice is about as low as you can get.

This is the nightmare of chaos and brutality liberals force upon the social order with their ideas of social equality and freedom. Uncouth people put on the clothes of the dignified, but remain heartless and devoid of compassion and morality. This treatment of liberals mirrors the Southern Radicalist viewpoint in which liberals are the lowest scum of 
humanity, for in Dixon's world they are ignorant, hypocritical dogooders that are out of touch with humanity and the human suffering they claim to be fighting to alleviate. In today's world, Dixon's books are frowned upon as racist, yet you put Clark Gable and Vivian Leigh in a Technicolor love story and it becomes a time honored television event on TBS and NBC.

The third theme is when order will be restored through the violence of a paramilitary group, the Ku Klux Klan, just like in The Birth of a Nation. The great infringement starts when Scarlett is attacked while she is traveling through Shantytown. "The black ape" rips open her clothes after a white man stops her wagon (Mitchell 525). In the movie, the attack on Scarlett must be avenged and it is the Ku Klux Klan with Scarlett's husband Mr. Kennedy and her beloved Ashley at the helm, that will "clean out those woods where you [Scarlett] were attacked." It's the paramilitary force of the Ku Klux Klan that must protect whites and their women when the United States Army will not. As Melanie says in the movie, "It's what many of our Southern Gentlemen have had to do for our protection."

This leads to the fourth theme of the storyline when order and equilibrium are restored through violence. The Ku Klux Klan's war on "those woods" is not the only violence that takes place when order is restored. Throughout the book and the movie there is a constant tension between Scarlett, who wants to live life on her own terms, and Rhett Butler, who sees the spirited Scarlett as a lively woman who is his match. The problem is that she is so thick headed she cannot see her true love before her. The only time this is really set straight is when Rhett is aggressive, especially when he gets drunk and rapes Scarlett. Scarlett wakes up in the morning a satisfied woman in bliss only to lose it when Rhett walks in to apologize and ask for a divorce.

Finding the second theme of The Birth of a Nation storyline, the white savior that is resurrected, in Gone with the Wind is problematic, and, yet, resurrection is a major component of the movie. Rhett Butler, Ashley, Melanie, and even Tara the family homestead go through resurrections when each is brought back from the dead. The central character Scarlett, a woman, nearly physically dies when she falls down the stairs and suffers a miscarriage. Spiritually her innocence dies with the South before she rises to give her "as God is my witness" dialog. She could be said to be resurrected again when she finally realizes that she loves Rhett Butler. It is this realization that finally puts her back into her social place when she begs Rhett to stay with her and professes her love. She is now willing to accept her proper place at Rhett's side, instead of him as a poor substitute for Ashley. In the end, it is the hope of re-establishing family by returning home, to Tara, and winning back Rhett that saves the 
day. This hope, a hope that was killed by the Union Army, is resurrected in Scarlett, the once independent woman who dresses more like a prostitute, who is brought back to the sanctuary and province of patriarchal order.

\section{Fort Apache (1948)}

Masculinity and what is a man is constantly in play throughout the story of the South and the lost cause, and it is also a basic element of Westerns in which men must face villains, hostile Natives, and survive Mother Nature. The cowboy in the Western is a man's man, a man among men in a world where few women exist. In many ways, the social order of the Western is similar to the old South in which women are either fallen prostitutes or proper married ladies. Similarly, the Old West is another game of contrasts, a struggle between life and death, and a place where the good guy wears a white hat and the bad guy wears a black one. The Western is almost a ready-made fit for The Birth of a Nation storyline and its four themes.

Fort Apache, from 1948, is the first installment of what many call director John Ford's cavalry trilogy, with the other films being She Wore a Yellow Ribbon (1949), and Rio Grande (1950). All three of Ford's cavalry trilogy: star John Wayne; are based upon James Bellah stories; the cavalry units include veterans from the United States Army and the Confederacy; and involve fighting the Apaches (Gallagher 254). Ford's non-conformist, revolutionary if you will, challenges to the status quo, such as exploding the hero myth, are acknowledged here, but this is not our concern. Our focus is on a conventionalized storyline common to Hollywood blockbusters. Another common trait to the films in Ford's trilogy is that they were all commercial hits. This is most assuredly due in large part to the artistry of Ford, the director, and the people who made the films. However, I would also argue this is in part due to a story that simultaneously issues challenges to social order, such as characterizing the Apaches with an uncommon degree of dignity for the day, while maintaining a larger status quo framework within a storyline that was familiar and safe to viewers.

The first theme that is familiar to viewers is that people of color, women, and liberals are a threat to family and social order. Ford makes it clear in his films that the Apache have family, order, and honor, but is it also clear they are still "the Other (Gallagher 249)." The Apaches are the enemy who will destroy civilization, just as they torture cavalry soldiers instead of just mercifully killing them. Apaches are the threat to white social order, so they must be isolated and contained.

The main female character in Fort Apache is Philadelphia Thursday, played by Shirley Temple. Philadelphia is the unmarried, sophisticated 
daughter of widower and new Commanding Officer Lieutenant Colonel Owen Thursday. She has returned from being educated in Europe, and, without a mother, Philadelphia represents the threatening potential of a woman coming of age who wants to be independent and does not know her place. This threat is quickly softened with the casting of Shirley Temple and her box office topping screen persona of innocence and her sugary smile. Philadelphia adopts the role of surrogate wife to her father when she attempts to put together a proper home from odds and ends furniture she has acquired from the limited offerings at the fort. Early in the film the potential threat of her becoming independent is cast off by her immediate falling in love and pursuit of Lieutenant O'Rourke, played by her then real life husband, John Agar.

Philadelphia's father, Commanding Officer Lieutenant Colonel Owen Thursday, played by Henry Fonda, is the liberal in Fort Apache. Lieutenant Colonel Thursday is the ultimate Yankee intellectual born in Boston and educated in the East, and, like his daughter, he has just returned from Europe, where he has been stationed and, no doubt, has been likewise corrupted by a sophisticated European world view.

In a Western cowboy world of contrasts, Lieutenant Colonel Thursday is the opposite of his second in command Captain Kirby York, played by John Wayne. Thursday is a socially awkward, clean, petite and thin-framed Fonda, a frail intellectual who wears white gloves and is prim and proper. Thursday is a martinet who follows the book codes and rules of rank. Captain York is tall, dirty, hair on his arms girthy John Wayne, whose bare hands are just as ready to shake hands in friendship as they are to form a fist ready for a brawl. York survives by virtue of his ability to read people and situations, and, unlike Fonda, his adroit social skills are responsible for his advancement and staying alive.

On too many fronts, Lieutenant Colonel Thursday is a replay of the liberal stereotype of Austin Stoneman from The Birth of a Nation. Stoneman was emasculated through his having to sit, use a cane, and wear a wig; and was a threat because of his disregard for family, such as having one chair at his dinner table. The chair comes back in Fort Apache when Thursday sits in a chair, the chair breaks, and he MUST be helped to his feet by his daughter Philadelphia and her servant Guadalupe. Thursday might as well have had a clubfoot. Thursday is not a real man, for me must be helped up to his feet by two women. Thursday is literally a feeble excuse of a man who cannot lift himself up by his own bootstraps. Similar to Stoneman, Thursday is awkward when his daughter goes to hug him, and he acts stiff and unassured. Similar to Stoneman, Thursday places his ideals ahead of family, such as when he is all too eager to leave his daughter's dinner party because of a general alarm. A disappointed Philadelphia ends up having dinner with a real 
family, the conservative Captain Sam Collingwood, Mrs. Collingwood, Captain York, and Lieutenant O'Rourke. Like Stoneman, Thursday cannot protect his own daughter. He knows where the Apaches are, but does not know where his own daughter is when she is out with Lt. O'Rourke, and yet Captain York knows where both the Apache are and where Lt. O'Rourke and Philadelphia are, as if York is her proper father, like when she is sitting next to him at the dinner table in the Collingwood home. In a strange admonishment of these roles the Commanding Officer Lt. Colonel Thursday defers to Captain York's paternal approval when he says, "I think I am within a father's right's Captain York. My daughter's life and safety are precious to me." Like the hug earlier, he is not sure and he doubts what family roles and responsibilities are.

The vilification of the North takes place in one of the longest scenes in Fort Apache, a scene that is supposed to serve as comic relief. Sergeant Beaufort, who was a major in the Confederate Army, asks the new recruits, "Did any of you gentlemen have the honor serving with the South arms of the late War Between the States?" One new recruit replies, "Yes sir. I had the pride, sir, of serving with Bedford Forest." Sergeant Beaufort gives the Private a promotion to Corporal, and tells the Corporal to show the "Yankees how to ride." The Corporal rides off like he is an expert and punctuates it with a rebel yell. The Yankee recruits try to mount, and they are a bunch of clowns falling off their horses. The first volunteer is the shortest, and he is thrown over the horse by one of the trainers. The ineptitude and inexperience of riding horses by the Yankees is supposed to be comic relief, but these gestations are hardly innocent as evidenced by the concluding bookend when the Corporal returns from galloping around and informs Sergeant Beaufort, "Sir, I beg to report I lost my Yankee cap." To this affront of being out of uniform, Sergeant Beaufort rewards the Corporal with not one handshake, but with three.

The third theme comes into being when Lt. Colonel Thursday forces the soldiers, who have supposedly disobeyed orders or violated his trust, to stay back with the supply wagons, for this includes Captain York and Lieutenant O'Rourke. Everyone, including Thursday, knows that the main unit is heading into an ambush where they will certainly die. It is their duty, and they follow orders anyway.

The only ones left living are Captain York, Lt. O'Rourke, and the supply people. The rest of the unit survives because John Wayne's character effectively surrenders to Cochise by taking off his weapons and walking out to receive the unit's flag. But this is one strange surrender where it would be customary for the highest-ranking officer of the defeated to give his sword or weapon to the victor. Captain York does not give his weapon to Cochise, nor does he give the unit's colors to 
Cochise. Cochise gives the colors to Captain York indicating the unit will live on. Captain York drops his weapons to the ground with his men indicating he will pick them up again when he returns to them. This is not surrender; this is an official's time out in which the defeated will return to fight again. It is "what Bogdanovich has called Ford's glory in defeat (Place 86)."

This leads to the second theme of the resurrection of white savior. J.A. Place, following Bogdanovich, notes:

What lives after that massacre is not Colonel Thursday or his men, but a tradition more important than any of them. ... The situation is so powerful that its tragedy is transcended by the force of destiny. There is more power in living out a myth than in winning a battle, and this is the key to many Ford films (Place 87-89).

The resurrection is not of a person per se, but is of the myth of a person and a unit. One of the last scenes is of Captain York answering newspaper reporters' questions about Lt. Colonel Thursday's charge. Captain York as Commanding Officer adopts Thursday's tact of formal response to the print media and also submission to rank, code, and system. Thursday's better traits live on in Captain York, and more importantly the cavalry unit lives on. The focus is on history, not the moment, and the audience finds security in the connection to the future of defeating, containing, and isolating the Apache that re-establishes white, patriarchal order.

\section{The OMega Man (1971)}

If The Ten Commandments represented the pinnacle of Charlton Heston's career as the main character in Hollywood's biggest budget films, it could be said The Omega Man represented his nadir as he slipped into being a leading man in low budget science fiction films. Interesting to note is in Gone with the Wind and Fort Apache, the four themes of The Birth of a Nation storyline where not all direct, or literal, correlations, but involved a complexity of translation. For example, in Fort Apache the resurrected savior is not an individual person per se, but is the personification of the unit and the myth of battle. However, under the cloak of science fiction we find direct correlations for all four themes in The Omega Man.

The movie is set four years into the future of 1975 when warfare breaks out between the Soviet Union and communist China, and this conflict devolves into one side or both employing biological weapons to gain tactical advantage. However, these biological weapons produce the horror of human destruction because they are killing everyone and no cure is 
known. Thus, the Soviet Union represents the evil liberals and communist China represents the evil people of color, so the first theme is the very source of destruction of the human race.

Early in the film we see Charlton Heston as the character Colonel Robert Neville in a helicopter carrying a case of a possible vaccine when the pilot starts going through the quick throes of the plague's death symptoms. Colonel Neville attempts to take over as pilot when he himself starts going through fast death symptoms as well. The helicopter crashes, and on his deathbed baptized in fire, Neville opens the case and injects himself with the vaccine. It works, but he becomes what we think is the sole survivor. Thus, he has died in a helicopter crash and been resurrected with clean blood and immunity to the scourge of liberalism and people of color.

Neville travels through the city gathering a new car, food, clothes, and gas. He returns home and he is confronted by the family, a group of survivors whose last stage of a prolonged death sees the victim become an albino and extremely sensitive to light. The family goes about burning library books, destroying the technology of the old order, and refusing to use the machines and weapons of the old order. Instead they use fire to destroy that which has brought destruction to the human race. Neville on the other hand embraces the technology that made him a biological researcher in the military and saved his life. He replaces human companionship with playing videotapes, records, and talking to mannequins, until he meets Lisa.

Neville first meets Lisa while he is clothes shopping and she is posing as a mannequin to escape his detection. Lisa, with her huge Afro, is very black, and her ability to survive the scourge makes her tough and the equal of Neville. She and Neville strike up a romance. Critics have been quick to cite Lisa's, played by Rosalind Cash, character and romance with Charlton Heston as a progressive advance for a film leading us into the future. However, Lisa as the last available woman is a commentary on what lengths have to be existent for this progress of equality to take place. But for every step forward in this venture, two are taken back, as Lisa represents not only blacks, but as the last woman, women as well.

A crucial part of the story is when Lisa develops the last stage of the disease and becomes albino, sensitive to light and confused. She rejoins the family and gives the keys to Neville's apartment to the leader of the family, allowing the family to capture Neville and attempt to execute him. Thus, blacks and women once again betray the social order and lead to the downfall of man. Thus, the first two themes are completed.

Themes three and four come together in the film when the white savior complex is completed in explicit symbolism. The third theme 
comes when Neville is shooting up the family with automatic assault rifles while wearing his colonel hat and gun holster, like a gunman in a western shootout. In the end, Neville is dying like Jesus on a modern sculpture that stands in for the cross. He hands a bottle of his blood, the serum, to Dutch and then expires. Thus, the fourth theme is completed as through his death, and blood humanity will be saved as Dutch drives a bus full of children to whom he will administer the serum. Through this new generation humanity and the social order will be re-established. The futuristic Omega Man is in the end a recycled rehash of killing liberals, people of color and women to re-establish the patriarchal order of the old South.

\section{The Outlaw Josie Wales (1976)}

The Outlaw Josie Wales begins when the old South is ending during the Civil War, and the movie presents another tale of the conservative male killing liberals in order to re-establish patriarchal social order. I agree with Drucilla Cornell's assessment that the film has anti-war sentiments and that Clintwood Eastwood is a complex person telling complex stories, more so than early critics were willing to grant him (Cornell 139; Foote xiii). However, I also agree with her assessment that Eastwood "works within traditional genres so that the imaginary that gives the films its seeming sense of shared meaning is both challenged and made explicit (Cornell 143-144)." Additionally, similar to Dixon and Griffith, Eastwood may be the storyteller of the film, but the script cannot escape the fact that it is based on a book written by a white supremacist and former Klan leader. The book, The Rebel Outlaw: Josey Wales, was written by Asa Carter, a notorious segregationist and speechwriter in the 1960s for the Governor of Alabama during George Wallace's infamous days as a white supremacist (Barra). Clint is the storyteller, but Carter is the storywriter, and Carter firmly operates within the conventions of The Birth of a Nation storyline.

From the beginning we are traveling in the province of demonizing liberals and those who fight for equality. Josie Wales is minding his own business, sitting out the Civil War, plowing his field when 'redleg' United States soldiers burn his house, kill his son, rape and murder his wife, and leave Josie for dead with a sword leaving a huge cut down his face. Squarely in the tradition of Dixon's vilification of real life abolitionists, Carter and Eastwood slander non-fictional abolitionist General James Lane by placing the Redlegs in this fictional atrocity under General Lane's command. General and Senator Lane, a real person who existed, represents the abolitionists and liberals, and in this fictional account he represents the most morally bankrupt human scum that walked the earth. Lane condones and prods the Redlegs into massacring, 
under a flag of truce, the Confederate unit Josie joined after the Redlegs massacred Josie's family. True to the tradition of Dixon and Mitchell, the war is over and the massacre of the Confederate unit makes no sense, but this is the chaos and nightmare that happens when liberals and people of color seize control. General Lane says of the massacre, "These men were decently treated. They were decently fed, and then they were decently shot. These men are common outlaws, nothing more." Can you imagine the outcry from Southerners if a real life Confederate General, such as Robert E. Lee, was slandered like this in a major motion picture?

Within, the first 20 minutes, the four themes in the storyline of The Birth of a Nation have been replayed in The Outlaw Josie Wales. Liberals and abolitionists have been demonized, and real life General and Senator Lane has been slandered in a most base portrayal. The white savior, pacifist Josie Wales, is killed, and is resurrected as a gunslinger for God exacting justice upon the evil Yankees to re-establish the social order from the chaos and hell the liberals forced onto the world. One thing gets in the way, and that is the end of the Civil War.

But for Josie, there is no end to the war. He refuses to surrender to General Lane, and he rides in to try to save his old unit, but most of them are gunned down, and he is only able to save mortally wounded Jamie, the youngest member of the unit. General Lane places a $\$ 5,000$ bounty on the head of Josie.

The rest of the film is road picture where along the way Josie is joined by Lone Watie, Little Moonlight, Grandma Sarah Turner, Granddaughter Laura Lee Turner, and Chato. This straggly band heads to live on Sarah's son's Crooked River Ranch, which is itself in the middle of Comanche land. Sarah's son, Tom, is dead, so the ranch is abandoned.

Josie Wales, the white savior, brings justice and peace to the hell and chaos brought by the evil liberals represented by the Redlegs and the United States government. Josie brings the North and South together when he takes Laura Lee Turner, a Jayhawker, as his wife. This marriage brings the orphaned and independent Laura Lee back within the confines of the family. Josie negotiates a peace with the Comanche through a pact of assured mutual destruction, very akin to the nuclear détente that was present in the 1970s and 1980s. The presence of Josie and the peace allows Chato to partner up with Laura Lee's grandmother, Sarah, an independent woman Josie cannot tame, and together they form an extended family. Sarah's son lives on by the continuance of family on the ranch he started. Lone Watie gains a lover with Little Moonlight, whom was freed from bondage by Josie. In the end, Josie kills Captain Terrill and the rest of the Red Legs that have come after him. The evil liberal has been slain, and family and the social order has been restored where those who have lost their families to the Civil War, including 
Josie, Sarah, Laura Lee, Watie, and Little Moonlight. The audience can now rest because the familiar formula has played out.

Audiences did find refuge in the familiar story. The Outlaw Josie Wales brought in a box office receipts that were roughly ten times the budget on which it was made (www.imdb.com/title/tt0075029/business? ref_=tt_dt_bus). Time magazine "hailed it as one of the year's ten best" and Orson Welles heaped praise onto the film while a guest on the Merv Griffin Show (Foote 32). Gone with the Wind, The Omega Man, and The Outlaw Josie Wales all play out with a similar backdrop of their genre not being en vogue upon release, yet all of them enjoy huge commercial success. But why should they not be successful when they share the same storyline as the box office smash The Birth of a Nation?

\section{DisCUSSION}

The storyline with the four themes in The Birth of a Nation has become conventional and familiar to audiences throughout the last century. Gone with the Wind, Fort Apache, and The Outlaw Josie Wales were all commercial hits that were critically acclaimed. Even The Omega Man, which made its money back and then some, but was not critically acclaimed, remains revered today with a cult following, which includes industry heavies, like Director Tim Burton (Davis, Dickinson, and Villarejo 406). The motion pictures reviewed herein are examples of how this conventional storyline plays out in romance films, Westerns, and science fiction films. These four themes can be found in countless other films, including Star Wars and The Lone Ranger. The point is the examples herein are by no means alone, for in a town where success breeds imitation you find this storyline in many of the top blockbusters of today.

The questions remains: "If the storyline in The Birth of a Nation itself is racist, sexist and violent shouldn't it make films using the same storyline no less repugnant?" At the very least, this storyline plants the seeds in our consciousness that Black Lives, liberals, and feminists are monsters threatening white, patriarchal power, and gun violence, not negotiation, is the way to terminate the threat. Currently, The Birth of a Nation remains a reviled and controversial film, while those films cut in its pattern remain popular and revered. The portrayals of blacks, liberals, and women in The Birth of a Nation are repugnant to most, yet the portrayals of liberals, such as Senator Lane, in The Outlaw Josie Wales is no less outlandish and yet the movie is critically acclaimed to this day. I propose one cause of this quandary, and by no means do I say it is the only one, is what I call social distance by layering.

I propose that seeing the meanings of symbols becomes harder when they are submerged in more layers in which the symbol is further removed from its original context. Layers may consist of time, technol- 
ogy, changes in meaning, or any 'thing' that further removes or hinders the audience from being aware of the original social context. To further explain this concept, I will use the example of time.

Thomas Dixon felt a direct connection to the Civil War, for he was born during its waning days. Dixon hated the Civil War, the end of slavery, the push for racial equality and black suffrage because he viewed it as being responsible for his family's economic misfortune. His uncle, who was a surrogate father for him, was a leader in the original Ku Klux Klan. Dixon is well connected and invested in knowing about real life Congressman Thaddeus Stevens, and has a strong hatred for him. He bases his caricature of the evil Congressman Austin Stoneman on Congressman Stevens, and this is familiar to his audience in 1915, merely fifty years after the Civil War's end, because Steven's indelible character and push for black equality was still fresh in the national consciousness. Thus, you have people like President Wilson who applauded the Stoneman portrayal as realistic, and then you have others, like the NAACP, that staunchly opposed it as a shrill distortion (Stokes).

However, you add on a layer of social distancing by taking a less well-known character, such as Senator Lane, and the real life person becomes obscured by a layer of anonymity. You make the movie a century removed from the war, and you have an entire audience that has no direct connection with the time period or its players. It is very conceivable that Director Clint Eastwood was not aware that Senator Lane was a real person, and it is much more likely that Eastwood was not aware the book The Rebel Outlaw Josie Wales was written by a former Ku Klux Klan leader. Even if Eastwood read about General Lane and the real life atrocities that took place under his command, he provides no counter of the real life atrocities by Quantrill's Raiders, such as the Lawrence Massacre, and their leader Bloody Bill Anderson, whose robbery and murder of civilians clearly are the actions of a psychopathic killer. Josie becomes a member of Quantrill's Raiders and we know this because Blood Bill Anderson identifies himself when this band of border ruffians ask Josie if he wants to join them. In the mythos of this movie, we are supposed to be sympathetic and understanding of Josie's wrath, and by extension Bloody Bill Anderson and every other member of Quantrill's Raiders, and we empathize with their search for 'justice' while we are provided no idea of the immorality and psychopathic sadism which took place in their robbery and execution of literally hundreds of civilians, including children. They are not thugs; they are out for justice just the same as any sane man would be. But in the mythos of this movie, Senator Lane and the Red Legs have no such complexity of character nor understanding. They are cold-blooded killers who engage in it for the joy of it under the 
charade of protecting people and pushing for equal rights of all races while hiding behind the authority of the United States.

Does this moral inversion seem familiar? It should because it is the same moral inversion that takes place in Gone with the Wind and countless other movies. Once again, in the opening scenes of Gone with the Wind we see blacks plowing fields and picking cotton. These blacks are in essence beasts of burden that feel no pain, whose backs do not sweat under the hot sun, nor do they feel the pain after hours upon hours of stooping and bending over. On the contrary, this horrific situation of slavery and oppression is presented as an idyllic fairytale with angelic choruses singing in the background. This is heaven, not hell. They are not human and do not deserve empathy or understanding. However, Scarlett's two sisters pick cotton and we can see the sweat on their brow and dirt on their faces, and we see close-ups of their hands and feel their pain. They are real human beings who deserve our empathy and understanding. Moral inversion takes place with the dehumanization of the truly downtrodden while the oppressor is shown as the victim who deserves our understanding.

Eastwood has been defended, and no doubt will continue to be defended, by those who argue every maker of motion pictures must operate within the conventions of the medium, and in the movies you have to have bad guys and good guys. This is my point exactly. In the real world, all things being equal, the bad guy is more likely to be the person that argues we must continue to oppress one group of people and the good guy is going to be the person that argues for equality and freedom of all people. However, in the real world The Birth of a Nation which established a medium as an art form, the conventions of its aesthetic and camera work, and also its distribution system; also established a conventional storyline in which the bad guy is the person who advocates equality and freedom for all people and the good guy is the person who says we must keep some people as slaves. This is the real world moral inversion that takes place in The Birth of a Nation and it is the conventional story that is propagated by Eastwood in The Outlaw Josie Wales, and no amount of defending it can change the fact that this moral inversion of reality is inexcusable and is no less repugnant than when the Klan rides into save the day to become heroes and use the threat of a gun to keep blacks from voting.

In the real world Eastwood could have told this same story from the point of view of a Jayhawker whose family was brutally murdered. But he did not. Let us be real for a second. Who is more likely to be a pacifist? An egalitarian abolitionist living in Lawrence, Kansas, or a white supremacist living in Missouri in the 1860s? The storyline in The Outlaw Josie Wales does not make sense in the real world, but its irrational- 
ity and moral inversion make perfect sense and commercial cents within the conventions of a medium in which the moral inversion of The Birth of a Nation establishes conventions.

The storyline from The Birth of a Nation becomes more distant and acceptable as each layer of new movie telling it is added. The storyline may be unfashionable, but wrap it in a layer of Technicolor and replace a white woman in black face with Hattie McDaniels and the storyline is resurrected like Scarlett O'Hara. Add another layer of distance by dressing it up in a different genre, say as a Western, and it becomes even harder to recognize while becoming more socially distant and acceptable. Hide it in science fiction and the key is, for the most part, thrown away forever. By 1976, the story has been told so many times, and so many layers have been added that even the same story written by a white supremacist beginning in the same time period of the original becomes unrecognizable. The tale has come full circle and it is told by a vaunted director which in turn leads to this telling being praised no less than by another hallowed director.

This exposé warrants further study, for it reveals a quandary of a repugnant storyline the film industry must come to terms with in a day when gun violence against Blacks, liberals, and women espoused as the solution on the big screen is reflected in the real world streets of our nation. The idea that a Black President and affirmative action are threatening to the social order where white males suffer an unjust loss of rightful power plays directly in The Birth of a Nation. This is not a coincidence, and it is the sad swan song played over and over by The Lost Cause of the South.

With the end of slavery, the so-called Southern gentleman is no longer supreme. His right to class privilege, of guaranteed inheritance, and perpetuation of an aristocratic social order in perpetuity has been undermined. In this time of uncertainty, the very question of what makes a white man a white man translates into the de facto what makes a man a man in a world where white males are thought of as not only being the standard for what it is to be male, but are also thought of as the standard for what it is to be huMAN.

The second line of research that needs further investigation is that this conventional storyline advocates violence as the solution for returning white males to power. The first theme tells the story of evil liberals, women and people of color threatening social order. However, the more alarming aspects are in themes three and four where the solution to the problem is for white males to re-establish patriarchal power by killing liberals, women, and people of color. Research on this topic is of particular expediency because of current events in the real world taking place where white men are shooting liberals, women and people of color 
in unprecedented numbers. As noted before, Blacks and Latinos constitute 30 percent of the population, but constitute 56 percent of the prison and jail population in the United States. However, when it comes to public mass shootings, Blacks and Latinos only comprise 24 percent of incidents from 2006 to 2016, and this number has been skewed because Blacks and Arab Americans account for 75 percent of the incidents thus far in 2016 (http://www.gannett-cdn.com/GDContent/mass-killings/index.html\#explore). Meanwhile, non-Hispanic Whites account for 39 percent of the prison population, but account for 55.5 percent of mass spree shooters (Leah). Does the rise in mass shootings of men with hatred towards women, Blacks, and liberals at churches in Kentucky and North Carolina, and of Representative Giffords parallel the resurgence of the commercial success of this storyline promoting the murder of women, Blacks, and liberals? After all, this storyline is overtly present in recent blockbusters such as Indiana Jones and the Kingdom of the Crystal Skull, Transformers Revenge of the Fallen, and others. Is there a link between the fables we tell our children, and the behaviors these children exhibit when they become adults? These are but a few of the questions Black Lives Matter and our nation must confront today.

\section{Works Cited}

1898 Wilmington Race Riot Commission. 1898 Wilmington Race Riot Report. Raleigh, NC: Research Branch, North Carolina Office of Archives, 2006. Web.

Barra, Alan. "The Education of Little Fraud." Salon (December 20, 2001). Web.

The Birth of a Nation. D.W. Griffith. Griffith Feature Films, 1915. Film.

Benjamin, Walter. The Work of Art in the Age of Its Technological Reproducibility and Other Writings on Media (Cambridge, MA: The Belknap Press of Harvard University Press, 2008). Print.

Brown, Karl. Adventures with D. W. Griffith. New York: Farrar, Straus and Giroux, 1973. Print.

Campbell, Joseph. Pathways to Bliss (Novato, CA: New World Library, 2004). Print.

Cook, Raymond A. Thomas Dixon. New York: Twayne Publishers, Inc., 1974. Print.

Cornell, Drucilla. Clint Eastwood and Issues of American Masculinity. New York: Fordham University Press, 2009. Print. 
Davis, Glyn, Kay Dickinson, and Amy Villarejo. Film Studies: A Global Introduction. New York: Routledge, 2015. Print.

Dixon, Thomas Jr. The Leopard's Spots: A Romance of the White Man's Burden - 1865 - 1900. New York: Doubleday, Page \& Co, 1902. Print.

. The Clansman: An Historical Romance of the Ku Klux Klan. New York: Grosset \& Dunlap, 1905a. Web.

- The Clansman: An American drama: From his two famous novels The Leopard's spots and The Clansman. New York: The American News Company, 1905b. Web.

Foote, John H. Clint Eastwood: Evolution of a Filmmaker. Westport, CT: Praeger, 2009. Print.

Fort Apache. Dir. John Ford. RKO Radio Pictures Corporation, 1948. Film.

Gallagher, Tag. John Ford the Man and his Films. Berkeley, CA: University of California Press, 1986. Print.

Gillespie, Michelle K. and Randall L. Hall eds. Thomas Dixon, Jr. and the Birth of Modern America. Baton Rouge, LA: Louisiana State University Press, 2009. Print.

Gone with the Wind. Dir. Victor Fleming. Loew's, Inc., 1939. Film.

Guerrero, Ed. The African American Image in Film. Philadelphia, Pennsylvania: Temple University Press, 1993. Print.

Haley, Alex and Malcolm X. The Autobiography of Malcolm X. New York: Balentine Books, 1992. Print.

Hardwell, Richard Ed. Margaret Mitchell's Gone with the Wind Letters, 1936 - 1949. New York: MacMillan Publishing Co., INC., 1976. Print.

Henderson, Robert M. D. W. Griffith: His Life and Work. New York: Oxford University Press, 1972. Print.

Highham, Charles. Cecil B. DeMille. New York: Charles Scribner's Sons, 1973. Print.

The Hunchback of Notre Dame. Dir. William Deiterle. RKO Radio Pictures, 1939. Film.

Lambert, Gavin. GWTW. New York: Bantam Books, 1976. Print.

Mitchell, Margaret. Gone with the Wind. New York: The MacMillan Company, 1936. Print.

Niderost, Eric. "The Birth of a Nation." American History, October, 2005: 60-80. Print. 
Okuda, Akiyo Ito. "“A Nation Is Born””: Thomas Dixon's Vision of White Nationhood and His Northern Supporters." The Journal of American Culture 32.3 (2009): 214-231. Web.

The Omega Man. Dir. Boris Sagal. Warner Bros. Pictures, 1971. Film.

The Outlaw Josie Wales. Dir. Clint Eastwood. Warner Bros. Pictures, 1976. Film.

Place, J.A. The Western Films of John Ford. Secaucus, NJ: The Citadel Press, 1974. Print.

Planet of the Apes. Dir. Franklin J. Schaffner. 20th Century Fox, 1968. Film.

Rogin, Michael. 'The Sword Became a Flashing Vision'. Representations 9 (Winter 1985): 150-195. Print.

Sakala, Leah. "Breaking Down Mass Incarceration in the 2010 Census: State-by-State Incarceration Rates by Race/Ethnicity". Prison Policy Initiative Report, May 28, 2014. http://www.prisonpolicy.org/ reports/rates.html accessed on September 28, 2016. Web.

Slide, Anthony. American Racist: The Life and Films of Thomas Dixon. Lexington, KY: The University of Kentucky Press, 2004. Print.

Snowden, Frank M. Before Color Prejudice: The Ancient View of Blacks. Cambridge, MA: Harvard University Press, 1991. Print.

Stokes Melvyn. D.W. Griffith's 'The Birth of a Nation': A History of the Most Controversial Motion Picture of All Time. Cary, NC: Oxford University Press, 2007. Print.

Teachout, Terry. "The Original Movie Mogul." Culture and Civilization (October 2010): 67-70.

Tyson, Timothy B. "Ghosts of 1898" special section H, Friday, November 17, 2006. Raleigh, NC: The News and Observer. Print.

Vaughn, Thomas. "Voices of Sexual Distortion: Rape, Birth, and SelfAnnihilation Metaphors in the Alien Trilogy," Quarterly of Journal Speech, Vol. 81, No. 4 (1995): 423-35. Print.

Vera, Hernan and Andrew Gordon. Screen Saviors: Hollywood Fictions of Whiteness. New York: Rowman \& Littlefield Publishers, INC, 2003. Print.

Yazdi, Mohammad Rezaie. "Hollywood Mission: America the New Israel." Asian Journal of Social Science 37 (2009): 305-314. Print. www.oscars.org/oscars/ceremonies/1940 accessed on December 5, 2016. www.gannett-cdn.com/GDContent/mass-killings/index.html\#explore accessed on September 27, 2016. Web. 
www.imdb.com/title/tt0075029/business?ref_=tt_dt_bus accessed on December 5, 2016. Web. 